\title{
Konceptualizacje KONIA a cel praktyczny internetowych apeli o darowizny na rzecz zwierząt
}

\author{
Conceptualizations of HORSE and the Practical Purpose \\ of Online Appeals for Animal Donations
}

\begin{abstract}
This study examines appeals for animal donations posted on the Internet by the Centaurus Foundation. The linguistic strategies in these terts have a specific purpose, which is to collect the money needed to save the life of a particular living horse from slaughter. The research carried out examines closely both the genre of appeal and the most common strategies used by addressers to elicit the attention of prospective receivers and to convince them to make contributions. Essential for this type of analysis is the use of the linguistic world image methodology, which makes possible the study of conceptualizations of animals to which such tests are dedicated. The imaging that results from a specific point of view increases the illocutionary power of the message.
\end{abstract}

Key words: applied tests, human - animal relations, pragmatics, linguistic imaging of the world

\begin{abstract}
Abstrakt: Przedmiotem analiz w opracowaniu są apele o darowizny na rzecz zwierząt, zamieszczane $w$ Internecie przez Fundację Centaurus. Działania językowe w obrębie tych tekstów są podporządkowane określonemu celowi - zebraniu pieniędzy potrzebnych na uratowanie życia konkretnemu koniowi przeznaczonemu na rzeź. Przeprowadzone badania przybliżają zarówno wzorzec gatunkowy apelu, jak i najczęstsze strategie stosowane przez nadawców w celu zjednania adresatów i nakłonienia ich do dokonywania wpłat. Istotne dla tych analiz wydaje się wykorzystanie metodologii językowego obrazu świata, pozwalającej na przedstawienie konceptualizacji zwierząt, którym poświęcane są te teksty. Obrazowanie wynikające z określonego punktu widzenia wpływa na zwiększenie siły illokucyjnej przekazu.
\end{abstract}

Słowa kluczowe: teksty użytkowe, relacje człowiek - zwierzę, pragmalingwistyka, językowy obraz świata

W definiowaniu języka możliwe jest przyjęcie różnych założeń interpretacyjnych: gramatyczno-strukturalnego, semantyczno-kulturowego czy też pragmatycznego. To ostatnie polega przede wszystkim na precyzowaniu warunków skuteczności wypowiedzi, pozwalających na wskazanie sposobów, w jakich ludzie (użytkownicy języka) oddziałują w procesie komunikacji na siebie i otaczający świat. Opis tekstu jako wytworu języka winien więc obejmować analizę struktury wypowiedzenia oraz wykorzystanych $w$ nim procedur semantycznych.

Wspomniane założenie stanowi w niniejszym opracowaniu podstawę analiz tekstów użytkowych funkcjonujących w różnych obszarach komunikacji. Tę grupę tekstów należy traktować jako intencjonalne działania językowe mające strukturalnie zamkniętą całość i odnoszące się do wybranych sfer życia codziennego. Elementem różnicującym wewnętrznie 
jest przede wszystkim ściśle określony cel warunkujący kompleksowe i składowe czynności nadawcy w ramach określonych typów działań (SoBSTYL, 2017: 349)1.

Teksty użytkowe są realizacją wzorca gatunkowego ${ }^{2}$, którego charakterystykę należy oprzeć na ściśle powiązanych z sobą parametrach: strukturalnym, pragmatycznym, poznawczym i stylistycznym (Wолтак, 2004: 51). W tym kontekście warto przyjrzeć się bliżej apelom o darowizny, zamieszczanym $w$ Internecie przez Fundację Centaurus - jedną z organizacji non profit działających na rzecz zwierząt. Zakres tej aktywności jest dość szeroki, zarówno pod względem sposobów udzielanego wsparcia (np. ratowanie życia, leczenie, rehabilitacja, przygotowania do adopcji), jak i gatunków zwierząt, którym ta pomoc jest niesiona. Główny nacisk Fundacja kładzie jednak na akcje wykupywania koni przeznaczonych na rzeź oraz zapewnianie im potem dożywotniej opieki w Zwierzęcym Folwarku w Szczedrzykowicach. Wymienione działania, zwłaszcza te o charakterze długofalowym, wymagają środków finansowych, których zdobycie jest możliwe dzięki wsparciu osób prywatnych, firm czy instytucji. By sprostać wszystkim potrzebom, przedstawiciele Fundacji za pośrednictwem dostępnych form komunikacji internetowej kierują do odbiorców apele o przekazanie darowizny na konkretny cel, zgodny z działaniem statutowym organizacji.

Analiza wzorca gatunkowego tych apeli będzie stanowiła punkt wyjścia do szczegółowych rozważań, dotyczących nie tylko aspektów pragmatycznych próśb, lecz także sposobów obrazowania zwierząt. Ze względu na to, że obiektem zainteresowania badawczego są apele na rzecz ratowania koni, zamieszczane przez wspomnianą fundację, poczynionych tu spostrzeżeń nie należy traktować jako uogólniających i wyczerpujących zagadnienie. Niniejsze opracowanie przybliża bowiem tylko przykłady strategii działania za pośrednictwem tekstu, w założeniu jest więc traktowane jako przyczynek do szerszych analiz.

Materiał stanowiący podstawę badań obejmuje apele pochodzące z lat 2019-2020, zamieszczane przez Fundację Centaurus zarówno na własnej stronie internetowej www.centaurus.org.pl czy Facebooku, jak i na portalu www.ratujemyzwierzaki.pl. Należy przy tym zaznaczyć, iż w przypadku nawiązania komunikacji z adresatami i za ich zgodą organizacja podtrzymuje kontakt, przesyłając drogą e-mailową widniejące na jej stronie aktualne prośby o wsparcie. Celem analiz jest wskazanie, jak w badanych tekstach obrazowane są zwierzęta i $w$ jaki sposób wyodrębnione konceptualizacje KONIA wpływają na siłę illokucyjną przekazu.

Analizowane apele o darowizny na rzecz zwierząt to teksty zorganizowane strukturalnie, zbudowane ze względnie stałych elementów charakterystycznych dla danego typu wypowiedzi. Nadawcy apeli reprezentują daną organizację i kierują przekazy do odbiorców (zainteresowanych poruszaną tematyką), często będących przedstawicielami grupy osób, które w miarę własnych możliwości i prawdopodobnie dość regularnie (m.in. dzięki skuteczności e-maili aktywizujących, za których pośrednictwem apele są wysyłane) wspierają finansowo działania Fundacji. Celem nadawców jest zachęcenie adresatów do dokonania wpłaty w dowolnej kwocie na rzecz konkretnego ratowanego zwierzęcia, tak by można było uzbierać odpowiednią, wskazaną w tekście sumę.

1 Por. także uwagi Marii Wojtak, według której teksty użytkowe można traktować jako zróżnicowaną grupę wypowiedzi okolicznościowych mających określone cele praktyczne (WoנTAK, 2019: 239).

${ }^{2}$ Za Wojtak gatunek traktuję jako abstrakcyjny twór, zbiór konwencji, „które podpowiadają członkom określonej wspólnoty komunikatywnej, jaki kształt nadać konkretnym interakcjom" (WoנTAK, 2004: 30). 


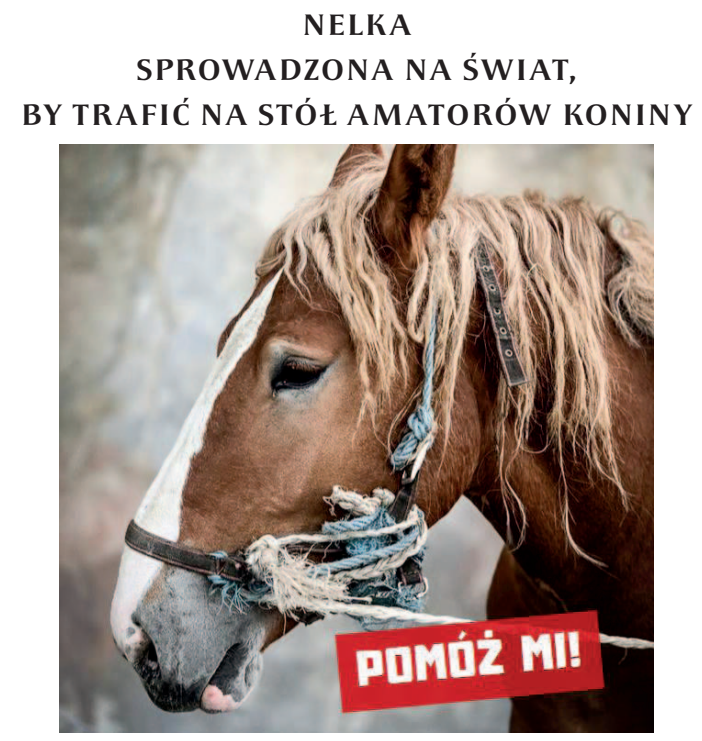

Krok za krokiem, noga za noga, z komórki wychodzi Nelka. Chwilę mruży oczy, nim przyzwyczają się do tak rzadko widywanego przez nią słońca. Jej piękna, złotoruda sierść mieni się $w$ ciepłym świetle. Kolejny skazaniec, o którego życiu i śmierci decyduje człowiek. Człowiek daje i zabiera. Nie wedle zasług czy przywiazania, ale wedle przydatności i możliwości zarabiania. To nie incydent, a proceder, z którym każdego dnia przychodzi nam się mierzyć.

My, ludzie, uprzywilejowany gatunek, możemy wszystko. Żywe, czujace zwierzęta sprowadziliśmy do roli przedmiotów użytkowych. I gdy staja się zbędne, z dnia na dzień traca miejsce $w$ naszym domu i życiu. Żyja, póki im na to pozwalamy. Później nie ma dla nich już nic.

Nelka ma tylko 2 lata. Nigdy nikomu nie była do szczęścia potrzebna. Sprowadzona na świat, by trafić na stół amatorów koniny, całe swoje życie spędziła w zamknięciu. Miała jeść i tyć, a nie ścigać się z wiatrem i innymi końmi.

To nie mięso, to jest Nelka. Koń skazany na rzeź. Nie dla ciebie, Nelko, rozległe padoki. Nie $w$ twojej grzywie zatańcza promienie zimowego słońca. Nie dla ciebie za kilka miesięcy zakwitna soczyste łąki. Dla ciebie, Nelko, jest rzeźnicki nóż. Takie konie, jak ty, rodza się z wyrokiem śmierci... Po to tu przyszłaś, dziś musi dopełnić się twoje przeznaczenie. Już idzie po ciebie śmierć... Nelka to jeszcze dziecko. Może żyć. Ale czy ktokolwiek zechce pomóc? Czy kogoś wzruszy los tego skazanego na rzeź konia? Jeśli możesz, to pomóż go ratować.

Nelka jest duża i ciężka - potrzeba 8450 zł, by za niq zapłacić. Potrzeba też 1100 zł na transport. Potrzebne sa też środki na odrobaczenie, szczepienie, kowala. Nelka będzie czekała na pomoc do końca stycznia. W Tobie jedyna dla niej nadzieja...

Za 4 dni mija termin, a brakuje jeszcze 2200 zł, by ja ocalić. 
Jeśli możesz, dokonaj darowizny

$z$ tytułem NELKA na konto

PKO BP15 102052260000600202200350

Fundacja Centaurus, ul. Wałbrzyska 6-8, 52-314 Wrocław

PAYPAL: kontakt@centaurus.org.pl

$z$ tytułem NELKA

Zbiórka $w$ serwisie www.ratujemyzwierzaki.pl

\section{ZA KAŻDA POMOC BARDZO CI DZIELKUJEMY!}

Za gatunkowy wzorzec kanoniczny apeli o darowiznę na rzecz zwierząt można uznać podstawową strukturę:

kto kiedy prosi o darowizna na rzecz kogo do kiedy + numer konta i tytuł wpłaty

W badanym materiale apele są najczęściej realizowane za pośrednictwem struktur alternacyjnych tworzonych przez dodanie do elementów obligatoryjnych wzorca kanonicznego między innymi nagłówków aktywizujących odbiorców do szybkiego działania. Przykładowo:

Kredka - czas do środy;

Alarm! Mamy 48 godzin, by ocalić Helenkę.

czy zwrotów o równie silnym nacechowaniu perswazyjnym, eksplicytnie wyrażających prośbę o ratunek dla konkretnego konia:

Bardzo prosimy, pomóż!;

Błagamy o pomoc dla staruszka Kajtka;

Prosimy, wesprzyjcie Kalinkę, dziś dla niej każda złotówka to szansa na życie.

Innym składnikiem struktur rozbudowanych są wprowadzenia tworzące ramę inicjalną przekazu, w których nadawcy wyrażają swój punkt widzenia na relacje homo - animal, negatywnie wartościując przy tym dość powszechną postawę opartą na antropocentryzmie widzenia świata, a wyrażającą się między innymi poprzez traktowanie zwierząt jak rzeczy. Przykładowo:

Jesteśmy uzurpatorami życia zwierząt. Ograbione z możliwości decydowania o sobie, moga liczyć jedynie na ludzka empatię, która często jest towarem deficytowym. Żyja, gdy sa potrzebne, gdy moga się przydać. Z chwila, gdy bardziej opłaca się zabić, jedna decyzja wysyłane są na rzeź. Nie znaja dnia ani godziny. To człowiek pozwala żyć i to życie też odbiera...

Jak wspomniano wcześniej, intencją nadawcy jest przede wszystkim zebranie w określonym czasie (zwykle chodzi o bardzo krótki, kilkudniowy termin) konkretnej kwoty pie- 
niędzy, która pozwoli na wykupienie danego konia od handlarza i umożliwi sfinansowanie kosztów transportu, na przykład:

Mamy tylko 48 godzin, by zebrać środki na odkupienie i transport Gucia (łącznie to $2000 \mathrm{zt}$ );

Cena życia Gniadego to 5000 zł. Wpłaciliśmy już 2000 zł, musimy pilnie dopłacić resztę - termin mija jutro, 12 maja.

Jeśli zwierzę wymaga leczenia, nadawca również o tym wspomina, przy czym tu rama czasowa dotycząca dokonywania wpłat najczęściej nie jest doprecyzowana, na przykład:

Potrzebne są też środki na profilaktykę weterynaryjna, na kastrację, na kowala.

Ewentualna aktywizacja odbiorców w tym względzie jest dokonywana zwykle przez użycie typowego dla badanych tekstów przysłówka intensyfikującego:

Dla samej Malwy pilnie potrzebna jest diagnostyka, która powie, na ile i czy w ogóle jesteśmy $w$ stanie poprawić komfort życia temu dzielnemu koniowi;

Ten zniszczony praca dla człowieka koń pilnie potrzebuje opieki weterynarza. Potrzebuje leczenia, bo niewyobrażalnie cierpi. Z winy ludzi...

Kwestia illokucji jest ściśle związana z różnorodnymi środkami językowo-stylistycznymi, wykorzystywanymi do zjednywania adresata. W apelach pojawiają się więc nie tylko bezpośrednie (wspomniane wcześniej) zwroty eksplicytnie wyrażające prośbę:

Prosimy ze wszystkich sił o pomoc dla Barnaby;

Błagamy Was o pomoc dla staruszka. Jesteśmy dla niego jedyną szansq na ratunek.

Nadawcy, by wpłynąć na adresata i zachęcić go do wsparcia finansowego, dającego szansę na uratowanie zwierzęcia, wykorzystują także powtórzenia, na przykład:

Bronka prosi o pomoc. Bo Bronka idzie na rzeź. Tak, na rzeź;

Malwa zamyślona, skupiona na swoim losie nie liczy już na nic. Nie dla niej zielone pastwiska ani obszerne wybiegi. Nie dla niej bieganie po łące i ściganie się z wiatrem.

Stosowana leksyka w dużej mierze nacechowana (prymarnie lub wtórnie) wartościująco, oddziałuje na emocje adresatów, ponadto dzięki niej nadawca wyraża swoją perspektywę

${ }^{3}$ Według Jerzego Bartmińskiego perspektywa to spójny obraz różnorodnych, ale wzajemnie uzupełniających się ujęć obiektu; stanowi ją zespół cech struktury semantycznej słów. Rozpoznanie tych cech przez odbiorcę pozwala na określenie przyjętego przez podmiot punktu widzenia (BARTMIŃSKI, 2007b: 78). 
obrazowania danego wycinka rzeczywistości. Tworząc przekaz w danej ramie sytuacyjnej, może więc założyć, iż odbiorcy będą reprezentować zbieżny system wartościowania i podobny punkt widzenia ${ }^{4}$, a to wzmacnia skuteczność oddziaływań perswazyjnych.

Renata Grzegorczykowa podkreśla, iż ocena tego, co jest pożądane, wymaga uwzględnienia subiektu odczuć i woli, a funkcję tę $w$ akcie komunikacji najczęściej pełni nadawca (Grzegorczyкowa, 2003: 263-266). Należy zaznaczyć, iż choć w badanym materiale dominujący treściowo obraz zwierzęcia (konia) jest przedstawiany właśnie przez nadawcę, to jednak można tu wyodrębnić konceptualizacje wynikające z trzech różnych (wpływających na wartościowanie obiektu) subiektywnych punktów widzenia:

1) samego nadawcy reprezentującego fundację ratującą konie przed śmiercią,

2) właściciela zwierzęcia, planującego jego sprzedaż,

3) osoby zajmującej się handlem końmis.

Nadawca jako subiekt odczuwający reprezentuje - wyraźnie czytelny $w$ analizowanych przekazach - pierwszy punkt widzenia. Dwa kolejne natomiast można wyekscerpować przede wszystkim na podstawie przedstawianej $w$ tekście relacji ze spotkania lub rozmowy z właścicielem konia oraz potencjalnym kupcem. Należy przy tym zaznaczyć, iż te punkty widzenia $w$ danej ramie sytuacyjnej nie są weryfikowalne i mają charakter subiektywnej kreacji dokonywanej $w$ tekście przez nadawcę, kreacji opartej na reprezentowanym przez niego systemie wartości, odnoszonym do relacji homo - animal.

W badanym materiale konceptualizacje KONIA są wieloaspektowe i opierają się nie tylko na wspomnianych, dominujących punktach widzenia. Złożoność tego zagadnienia wymaga szerszych analiz, wykraczających poza ramy przyjęte $w$ niniejszym opracowaniu, w związku z tym w dalszej części wywodu przybliżone zostaną jedynie te sposoby obrazowania, które można wyodrębnić na podstawie wyrażeń tekstowych odnoszących się do najczęściej eksponowanych cech przypisywanych zwierzęciu.

Podstawę metodologiczną stanowi tu teoria metafor konceptualnych, dzięki której możliwe jest odtworzenie semantycznego podobieństwa obu tematów metafory (zgodnie z formułą „S jest P"), czyli relacji będącej podstawą spójności całego wyrażenia6. W odniesieniu do omawianej tu sytuacji komunikacyjnej już samo działanie polegające na zamieszczaniu apelu świadczy o tym, że dla nadawcy każde zwierzę jest DOBREM, a więc istotą wartościowaną pozytywnie. W takiej konceptualizacji dominuje aspekt etyczny ${ }^{7}, w$ którym obrazuje się KONIA jako ISTOTE MAJACA PRAWO DO ŻYCIA, na przykład:

${ }^{4}$ Punkt widzenia traktuję tu za Bartmińskim jako czynnik determinujący sposób widzenia, a tym samym mówienia o obiekcie, co narzuca niejako jego kategoryzację. Zależność ta ma podłoże nie tylko podmiotowe, ale i kulturowe. Należy zaznaczyć, iż punkt widzenia różnicuje znaczenia słowa i sposoby konceptualizacji (BARTMı́́sKı, 2007a: 82).

${ }^{5}$ Zagadnienie szeroko rozumianego językowo-kulturowego obrazu KONIA w polszczyźnie stało się przedmiotem analiz w wielu opracowaniach. Por. m.in.: BArtmińskı, 1980; ANusieWICZ, 1992; GARDZIŃSKA, 2016; S七AWKOWA, 2016.

${ }^{6}$ Szerzej na ten temat w pracach: LAKoff, Johnson, 1988; ТокаRsкı, 1988; 2013 i in.

${ }^{7}$ Aspekty (inaczej podkategorie lub fasety) uznaję za Bartmińskim i Stanisławą Niebrzegowską za ramę subiektywnych operacji językowo-pojęciowych (profilowania), dokonywanych w celu kształtowania obrazu przedmiotu (BARTMIŃSKI, NiEBRZEGowSKA, 1998: 212). 
A przecież masz serce i one tė̇ mają. Masz oczy, jak i one. Masz słuch i one też słysza. Masz mózg, one też go maja, więc czemu tak wiele osób odbiera im prawo do życia, traktując je jak rzecz? One myśla, czuja, tęsknia, kochaja. I chca żyć. Tak samo jak my. Nawet wtedy, gdy sa schorowane czy stare.

Dla nadawcy KOŃ to także ISTOTA, KTÓRA NALEŻY RATOWAĆ, gdyż w aspekcie etycznym każde życie stanowi wartość:

Mamy czas do 20 lutego, aby zebrać środki i zabrać Marynę z szeregu tych, które służą zawsze do końca, do ostatniego tchu. Niech jej ostatni oddech ma miejsce u nas, za kilka lat. Czy to coś zmieni? Dla wszystkich koni niewiele. Dla niej wszystko.

Przywołany tu przykład wskazuje na konceptualizację KONIA jako ISTOTY WARTOŚCIOWEJ także $w$ aspekcie psychospołecznym. Nadawca wskazuje bowiem w wielu apelach na cechy wierności, oddania i pracowitości jako dominujące $w$ charakterystykach tego zwierzęcia.

KOŃ z punktu widzenia nadawcy jest również konceptualizowany jako ISTOTA WYKORZYSTYWANA PRZEZ CZŁOWIEKA, na przykład:

Latami, gdy zarabiał, starczało na garść owsa i dach nad głowa, gdy przyszła niedołężność i choroba, nawet na litość zabrakło miejsca. Bez skrupułów ktoś wysłał tego dziadka na rzeź.

Zwierzę obrazuje się więc jako OFIARE. Motyw skazania na śmierć przywoływany jest przy tym niemal $w$ każdym apelu, na przykład:

Zmęczona, spracowana, w podzięce za lata służby u człowieka dostała wyrok.

Nadawca ze swojej perspektywy oglądu danego wycinka rzeczywistości przypisuje właścicielom koni zainteresowanych ich sprzedażą inny sposób konceptualizacji tych zwierząt. W analizowanych apelach kreowana jest dwubiegunowość wartościowania, ujęta w ramy aspektów użytkowych, materialnych i czasowych, w których KOŃ jest DOBREM dla właściciela, ale tylko do momentu, gdy przynosi mu zyski lub swoją pracą pokrywa koszty utrzymania. Z takiego punktu widzenia wysoko ceniona jest więc przydatność zwierzęcia $w$ gospodarstwie, klubie jeździeckim, pozytywnie wartościuje się także jego płodność itp. Dopóki koń spełnia oczekiwania właściciela w tej mierze, dopóty zasługuje na opiekę i wart jest inwestycji. Ta konceptualizacja KONIA ulega przewartościowaniu w chwili, gdy zwierzę przestaje być użyteczne. Nieprzydatny ze względu na utratę sił, naturalny proces starzenia się, słabszą płodność czy choroby koń staje się bezwartościowy, a w związku z tym stanowi OBCIĄŻENIE dla właściciela. Przykładowo:

Nikt nie chce trzymać darmozjada, a już tym bardziej nikt nie chce takich zwierzat leczyć. Zużyte, wyeksploatowane do cna traca prawo do życia;

Stary w naszym społeczeństwie to synonim słowa "zbędny"; 
Po prostu stała się nagle bezużyteczna, gdy straciła wzrok. Z tego, co wiemy, pracowała $w$ rekreacji pod dziećmi, a na ślepym koniu się nie jeździ.

Nadawca, przybliżając $w$ apelach historie ratowanych koni, wyraźnie eksponuje antropocentryczną perspektywę relacji homo - animal, którą przypisuje właścicielom pozbywającym się swojej własności.

Człowiek $w$ swojej nieograniczonej władzy podzielił zwierzęta na te godne opieki i te do zjedzenia. Ale gdzieś pomiędzy tymi kategoriami balansuja konie. Jednego dnia kochane i zadbane, następnego traca prawo do życia. Makary stanq̨ł u handlarza z tej samej przyczyny, z której trafiają tam wszystkie konie. Ktoś jedna decyzja odebrat mu prawo do życia.

W przytoczonym przykładzie władzę człowieka nad zwierzęciem uwydatnia połączenie wyrazowe jedna decyzja. Pojedynczość w tym wypadku wskazuje na autorytatywność działań, przy czym zestawiona z cechą powszechności, potwierdzoną wyrażeniem wszystkie konie jeszcze bardziej eksponuje właściwie nieograniczone możliwości człowieka w kwestii decydowania o losie zwierząt. Według nadawców decyzja podejmowana przez dotychczasowego właściciela jest skazywaniem konia na śmierć, o czym wielokrotnie wspomina się w tekstach próśb o darowiznę:

Stał się zbędny, więc dostał wyrok;

Jedna decyzją sq wysyłane na rzeź;

Bo moment, w którym uznano Czesię za bezużyteczna, to moment, w którym stała się już tylko mięsem.

Zgodnie z perspektywą nadawczą taki sposób obrazowania przypisuje się nie tylko właścicielowi, lecz także osobie, która decyduje się na kupno zwierzęcia. Z punktu widzenia handlarzy KOŃ również jest DOBREM, ale w aspekcie materialnym ${ }^{8}$ Konceptualizacja obejmuje traktowanie zwierzęcia jako TOWARU, którego wartość przelicza się na kilogramy wagi, jest więc tylko MIESEM:

Handlarska waga wyceniła jego życie na 7100 zł;

Za Jagnę chce - wspaniałomyślnie... - tyle co rzeźnia. 880 kilo y 12 zt. To 10560 zł. Specjalnie na tę rozmowę sprawdzit, że kilogram koniny właśnie tyle kosztuje. Wszak jest człowiekiem biznesu, co podkreślił wielokrotnie.

Poczynione analizy pozwalają na wstępne wyodrębnienie kategorii składających się na różne (choć nie jedyne $w$ badanym materiale) konceptualizacje KONIA $w$ tekstach pełniących funkcję apeli o darowiznę na rzecz zwierząt. Można założyć, iż dla tych obrazów

${ }^{8}$ Por. uwagi Joanny Tyki $w$ artykule poświęconym sposobom prezentacji zwierząt sprzedawanych na targach konnych (TYKA, 2016), w których obrazowanie KONIA jest ujęte z innej perspektywy. 
wspólną wartością nadrzędną jest DOBRO, ale rozpatrywane $w$ różnych aspektach, z różnych punktów widzenia i perspektyw, a to wpływa na odmienność konceptualizacji (tab. 1):

Obrazowanie KONIA

\begin{tabular}{|c|c|c|}
\hline Punkty widzenia & \multicolumn{2}{|c|}{ Konceptualizacje KONIA } \\
\hline \multirow[t]{4}{*}{ Punkt widzenia nadawcy apelu } & \multicolumn{2}{|c|}{ zwierzę jako obiekt wartościowania } \\
\hline & \multicolumn{2}{|c|}{$\begin{array}{c}\text { DOBRO w aspekcie etycznym } \\
\text { WARTOŚĆ w aspekcie psychospołecznym } \\
\text { ISTOTA, KTÓRA CZUJE } \\
\text { ISTOTA, KTÓRA MA PRAWO DO ŻYCIA } \\
\text { ISTOTA, KTÓRA NALEŻY URATOWAĆ } \\
\text { OFIARA CZŁOWIEKA } \\
\text { dominujące aspekty wartościowania: etyczny } \\
\text { i psychospołeczny }\end{array}$} \\
\hline & \multicolumn{2}{|c|}{ cechy konia } \\
\hline & \multicolumn{2}{|c|}{ wierność, pracowitość, oddanie człowiekowi } \\
\hline \multirow{4}{*}{$\begin{array}{c}\text { Kreowany } \\
\text { punkt widzenia właściciela }\end{array}$} & \multicolumn{2}{|c|}{ zwierzę jako obiekt wartościowania } \\
\hline & \multicolumn{2}{|c|}{$\begin{array}{c}\text { DOBRO w aspekcie użyteczności } \\
\text { WARTOŚĆ w aspekcie materialnym } \\
\text { WŁASNOŚĆ } \\
\text { ISTOTA, KTÓRA SWOJA PRACA PRZYNOSI KORZYŚCI } \\
\text { dominujące aspekty wartościowania: użyteczności } \\
\text { i materialny }\end{array}$} \\
\hline & \multicolumn{2}{|c|}{ cechy konia } \\
\hline & $\begin{array}{c}\text { pożądane: } \\
\text { pracowitość, siła fizyczna, } \\
\text { płodność, zdrowie, } \\
\text { posłuszeństwo }\end{array}$ & $\begin{array}{c}\text { nieakceptowane: } \\
\text { starość, choroba, utrata sił } \\
\text { fizycznych, bezpłodność, } \\
\text { kalectwo }\end{array}$ \\
\hline \multirow{4}{*}{$\begin{array}{c}\text { Kreowany } \\
\text { punkt widzenia handlarza }\end{array}$} & \multicolumn{2}{|c|}{ zwierzę jako obiekt wartościowania } \\
\hline & \multicolumn{2}{|c|}{$\begin{array}{c}\text { DOBRO w aspekcie materialnym } \\
\text { TOWAR } \\
\text { MIESO } \\
\text { dominujący aspekt wartościowania: materialny }\end{array}$} \\
\hline & \multicolumn{2}{|c|}{ cechy konia } \\
\hline & $\begin{array}{l}\text { pożądane: } \\
\text { duża waga }\end{array}$ & $\begin{array}{l}\text { niepożądane: } \\
\text { niska waga }\end{array}$ \\
\hline
\end{tabular}

Źródło: Opracowanie własne.

Badane apele funkcjonują $w$ przestrzeni internetowej jako przekazy wykorzystujące różnorodne strategie przyciągające uwagę odbiorców, ale też przekazujące określone idee i propagujące pewne wzorce zachowań. W opracowaniu przedstawiono tylko niewielki ich wycinek, niemniej jednak zasygnalizowana tutaj problematyka pozwala na dokonanie kilku spostrzeżeń.

W apelach o darowiznę na rzecz zwierząt, tworzonych przez osoby reprezentujące Fundację Centaurus wyraźnie widoczny jest cel działań językowych. Teksty te, dzięki możliwościom, jakie dają różnorodne formy komunikacji internetowej, mogą docierać do bardzo dużej grupy odbiorców, a to daje większe szanse na skuteczność wyrażanych próśb. Naj- 
ważniejszym i najbardziej rozbudowanym elementem struktury apelu są charakterystyki ratowanych koni, na podstawie których możliwe jest przedstawienie obrazowania tych zwierząt z określonych punktów widzenia.

Wykorzystanie $w$ badaniach pragmalingwistycznych metodologii językowego obrazu świata pozwala na dogłębniejsze przedstawienie parametru poznawczego $w$ omawianym typie tekstu użytkowego. Wydaje się to szczególnie przydatne $w$ analizach dotyczących zarówno sposobów przedstawiania (konceptualizacji) obiektów stanowiących centrum zainteresowania nadawcy, jak i motywacji podejmowania działań językowych oraz - szerzej rzecz ujmując - tekstowych. Jak wspomniano na początku, wnioski wynikające z przeprowadzonych tu wstępnie rozważań warto zweryfikować, analizując prośby o wsparcie kierowane do odbiorców przez inne fundacje działające na rzecz zwierząt.

\section{Źródła}

https://centaurus.org.pl; data dostępu: 20-25.09.2020

https://www.facebook.com/fundacjacentaurus; data dostępu: 20-25.09.2020

https://www.ratujemyzwierzaki.pl/centaurus; data dostępu: 20-25.09.2020

\section{Literatura}

Anusiewicz J., 1992: Koń - jaki jest - w języku polskim? „Prace Filologiczne” XXXVII, s. 201-212.

Bartmiński J., 1980: Koń. W: Adamowski J., Bartmiński J., Hernas C.: Słownik ludowych stereotypów językowych. Zeszyt próbny. Wydawnictwo Uniwersytetu Wrocławskiego. Wrocław, s. $119-144$.

BARtMińskı J., 2007a: Polska dola, rosyjska sud'ba. W: BARtmińskı J., red.: Językowe podstawy obrazu świata. Wydawnictwo Uniwersytetu Marii Curie-Skłodowskiej. Lublin, s. 242-251.

BARTMIŃSKı J., 2007b: Punkt widzenia, perspektywa, językowy obraz świata. W: BARTMIŃSKI J., red.: Językowe podstawy obrazu świata. Wydawnictwo Uniwersytetu Marii Curie-Skłodowskiej. Lublin, s. $76-88$.

Bartmiński J., Niebrzegowska S., 1998: Profile a podmiotowa interpretacja świata. W: BartmińSKI J., TокARSKI R., red.: Profilowanie w języku i tekście. Wydawnictwo Uniwersytetu Marii Curie-Skłodowskiej. Lublin, s. 211-235.

GARdzıŃSKA J., 2016: KOŃ $w$ polskiej antroponimii $i$ toponimii. W: SzYMoniK D., JASıŃSKA M., SIE-

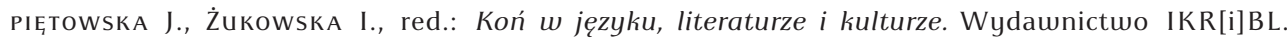
Siedlce, s. 13-26.

GRZEgorczyKowA R., 2003: Jeszcze $w$ sprawie rozumienia dobra $i$ dobroci. W: BARTMIŃSKI J., red.: Język $w$ kręgu wartości. Studia semantyczne. Wydawnictwo Uniwersytetu Marii Curie-Skłodowskiej. Lublin, s. 261-272.

Lakoff G., Johnsosn M., 1988: Metafory $w$ naszym życiu. Krzeszowskı T.P., tłum. Wydawnictwo PIW. Warszawa.

SŁAWKowA E., 2016: Miejsce konia w szlachecko-chłopskim imaginarium: perspektywa językoznawcy. W: SкоRUрSкA-RAczYŃska E., Rutкowska J., red.: Koń w kulturach świata. Wydawnictwo Naukowe Akademii im. Jakuba z Paradyża. Gorzów Wielkopolski, s. 149-160. 
Konceptualizacje KONIA a cel praktyczny internetowych apeli...

Sobstyl K., 2017: „To jest Bond - nie James, ale szczeniak”. Internetowe ogłoszenia adopcyjne jako przykład tekstu użytkowego. W: Hofman I., KęPA-Figura D., red.: Współczesne media. Gatunki $w$ mediach. Prace dedykowane Profesor Marii Wojtak. Gatunki w mediach elektronicznych. T. 2. Wydawnictwo Uniwersytetu Marii Curie-Skłodowskiej. Lublin, s. 349-358.

ТокARSKI R., 1988: Konotacja jako składnik słowa. W: BARTMińSKı J., red. Konotacja. Wydawnictwo Uniwersytetu Marii Curie-Skłodowskiej. Lublin, s. 35-54.

Tока SкI R., 2013: Światy za słowami. Wykłady z semantyki leksykalnej. Wydawnictwo Uniwersytetu Marii Curie-Skłodowskiej. Lublin.

ТүкА J., 2016: Kup pan konia! Sposoby prezentacji konia w rozmowie handlowej na współczesnym targu końskim. W: Szymonik D., Jasıńska M., Siepietowska J., Żukowska I., red.: Koń w języku, literaturze i kulturze. Wydawnictwo IKR[i]BL. Siedlce, s. 79-97.

Wолтак M., 2004: Wzorce gatunkowe wypowiedzi a realizacje tekstowe. W: OstASzEWSKA D., red.: Gatunki mowy i ich ewolucja. T. 2: Tekst a gatunek. Wydawnictwo Uniwersytetu Śląskiego. Katowice, s. 29-39.

Wojtak M., 2019: Wprowadzenie do genologii. Wydawnictwo Uniwersytetu Marii Curie-Skłodowskiej. Lublin. 